\title{
Selection of Coffea canephora parents from the botanical varieties Conilon and Robusta for the production of intervarietal hybrids
}

\section{Leilane Nicolino Lamarão de Oliveira ${ }^{1}$ Rodrigo Barros Rocha ${ }^{2^{*}} \odot$ Fábio Medeiros Ferreira $^{1}$ Victor Mouzinho Spinelli ${ }^{2}$ André Rostand Ramalho ${ }^{2}$ Alexsandro Lara Teixeira ${ }^{2}$}

${ }^{1}$ Instituto de Ciências Exatas e Tecnologia, Universidade Federal do Amazonas (UFAM), Itacoatiara, AM, Brasil.

${ }^{2}$ Empresa Brasileira de Pesquisa Agropecuária (Embrapa), Centro de Pesquisa Agroflorestal de Rondônia, 76815-800, Porto Velho, RO, Brasil. E-mail: rodrigo.rocha@embrapa.br. "Corresponding author.

ABSTRACT: The objective of this research was to quantify the genetic divergence of potential Coffea canephora parents, with the goal of developing progenies that associate the best traits of the Conilon and Robusta botanical varieties for hybrid vigor expression. Thus, 10 morphological and productive characteristics of 130 clones of Conilon and Robusta botanical varieties and their intervarietal hybrids were evaluated over 2 years. The experiment was conducted in a randomized block design with four replicates of four plants per plot. For selection of parents, the main component analysis was used to associate values with reference points obtained from the average of each botanical variety. The first two principal components allowed for the separation of the botanical varieties representing the variability contained in the original data with $76 \%$ for the first year and $69 \%$ for the second year. Although, the genotype $\times$ years interaction had significant effects, there were minor differences in the grouping from one year to the next, which is associated with the higher repeatability estimates observed in this study. It

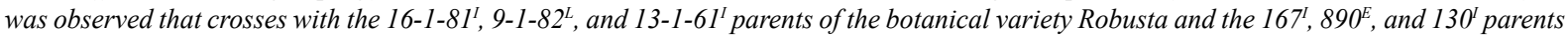
of the Conilon botanical variety presented greater potential for obtaining selection gains.

Key words: Coffea canephora, genetic divergence, heterosis.

Seleção de genitores de Coffea canephora das variedades botânicas Conilon e Robusta visando à produção de híbridos intervarietais

RESUMO: $O$ objetivo deste trabalho foi quantificar a divergência genética entre matrizes de C. canephora visando desenvolver progênies que associem características das variedades botânicas Conilon e Robusta à expressão do vigor do híbrido. Para isso, foram avaliadas dez características morfológicas e produtivas de 130 clones das variedades botânicas Conilon, Robusta e de híbridos intervarietais, ao longo de dois anos, em delineamento de blocos casualizados com quatro repetições de quatro plantas por parcela. Para seleção de genitores foi utilizada a técnica de componentes principais associada a pontos referenciais obtidos a partir da média de cada variedade botânica. Os dois primeiros componentes principais permitiram a separação das variedades botânicas e dos híbridos intervarietais com uma representação da variabilidade contida nos dados originais de $76 \%$ no primeiro ano e $69 \%$ no segundo ano. Apesar da significância da interação genótipos $x$ anos, observou-se pouca diferença no agrupamento ao longo do tempo, o que está associado às maiores estimativas de repetibilidade

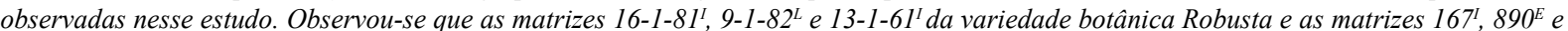
$130^{I}$ da variedade botânica Conilon apresentaram maior potencial para a obtenção de ganhos com a seleção.

Palavras-chave: Coffea canephora, divergência genética, heterose.

\section{INTRODUCTION}

Coffea canephora accounts for approximately $35 \%$ of the world coffee production and is characterized by high vegetative vigor and productivity (INTERNATIONAL COFFEE ORGANIZATION, 2016). It is an allogamic species that is characterized by gametophytic self-incompatibility and synchronized flowering, mechanisms that naturally favor cross-pollination (PARTELLI et al., 2011; SOUZA et al., 2013).

This species presents two botanical varieties with distinct characteristics that are commercially cultivated (DAVIS et al., 2006; BATISTA-SANTOS et al., 2011). The botanical variety Robusta is characterized by erect growth, larger leaf size, higher average sieve, late maturation, less tolerance to water deficit, and greater resistance to diseases and pests. The botanical variety Conilon is characterized by shrub growth, early maturation, elongated leaves, greater tolerance to drought, and greater susceptibility to pests and diseases (MONTAGNON et al., 2012; SANTOS et al., 2017).

The superior performance of plants because of crossings between genetically contrasting 
individuals is a characteristic of this species. The heterosis or vigor of the hybrid is expressed in the hybridization between divergent parents, and the selection of matrices should simultaneously consider the superior agricultural merit and greater genetic diversity (RESENDE, 2015; DIAS et al., 2004). MONTAGNON et al. (2008) observed that progenies of genetically divergent crosses presented yields of 20 to $50 \%$ above the mean controls. LEROY et al. (1997) and FERRÃO et al. (2008) also reported the greatest potential productivity of divergent hybridizations.

Predictive methods that allow quantification of genetic variability without the need for cross-breeding, support the selection of matrices with the highest potential for hybridization (RESENDE \& DUARTE, 2007; ROCHA et al., 2015). Selection of parents can be performed using assessments of agronomic performance and genetic variability in different stages (DIAS et al., 2004). With the goal of selecting parents by interpreting both genetic diversity and agronomic performance, the main component analysis associated with the reference points was used (NASCIMENTO et al., 2009; ROCHA et al., 2005). This strategy differentiates itself by allowing the simultaneous evaluation of a large number of accesses with reduction of original dimensionality and minimal loss of information.

The objective of this study was to quantify the genetic divergence among 130 clonal accessions of $C$. canephora of the botanical varieties Conilon and Robusta, as well as interspecific hybrids, to recommend crosses between parents of greater productivity potential and greater genetic divergence.

\section{MATERIALS AND METHODS}

In December 2011, an experiment was conducted in the experimental field of Embrapa in the municipality of Ouro Preto do Oeste - RO $\left(10^{\circ} 37^{\prime} 03^{\prime \prime} \mathrm{S}\right.$ and $\left.62^{\circ} 51^{\prime} 50^{\prime \prime} \mathrm{W}\right)$, with a randomized block design with four replications, four plants per plot and spacing of $3 \times 2 \mathrm{~m}$. The goal was to evaluate the genetic diversity of 130 clones of the botanical varieties Conilon and Robusta, as well as, hybrids among these varieties. Cultural treatments were performed according to MARCOLAN et al. (2009).

For quantification of genetic variability, the following characteristics were evaluated in the agricultural years of 2014-2015 and 2015-2016: plant height (PHEI), number of productive plagiotropic branches (NPLAG); distance between rosettes of the intermediate part of the plagiotropic branch (DROS); number of grains per rosette of the intermediate part of the plagiotropic branch (GROS); number of rosettes per plagiotropic branch (NROS); and plagiotropic branch length (PLAGL). Maturation time was determined using the criterion that the plant has $70 \%$ of fruits in the cherry stage, with the record of the date of harvest (NDAYS). Genotypic values of the production per plot (VGProd) were estimated based on the weight of processed grains. In turn, the grain size was evaluated individually using a set of 12 different sieves from samples of $250 \mathrm{~g}$ of processed coffee (PEN). Leaf length and width (LLEN, LWID, respectively) were estimated from the evaluation of 10 leaves collected from the middle third of the plant and measured using a digital caliper.

Analysis of variance (ANOVA) was performed according to the statistical model $\mathrm{Y}_{\mathrm{ijk}}=\mathrm{m}+\mathrm{B}_{\mathrm{k}}+\mathrm{G}_{\mathrm{i}}+\mathrm{A}_{\mathrm{j}}+\mathrm{GA}_{\mathrm{ij}}+\mathrm{e}_{\mathrm{ijk}}$, where: $\mathrm{Y}_{\mathrm{ijk}}$, was the observation in the $\mathrm{k}$-th block, evaluated in the $\mathrm{i}$-th genotype and $\mathrm{j}$-th year; $\mathrm{m}$, mean of the assay; $B_{k}$, effect of block $k ; G_{i}$, effect of genotype $i$; $A_{j}$, effect of year $j ; G_{i j}$, effect of interaction between genotype $\mathrm{i}$ and year $\mathrm{j}$; and $\mathrm{e}_{\mathrm{ijk}}$, random error associated with observation ijk. In the estimation of genetic parameters the effects of environment were considered as fixed and those genotypes as random effects. Coefficient of repeatability was estimated to interpret the differential performance of the genotypes over the time (CRUZ et al., 2014).

To quantify the genetic divergence, the main component analysis was used, associated with the reference points denominated centroids, obtained from the average behavior of each botanical variety (ROCHA et al., 2005; NASCIMENTO et al., 2009). This technique allowed the estimation of abstract and independent variables to represent the maximum of the total variation contained in the original variables, while allowing for reduction of the dimensionality of the dataset with minimal loss information (CRUZ et al., 2014). Centroids were used to interpret the grouping of genotypes in relation to the characteristic botanical varieties.

The selection gain, which measures genetic progress in the next generation, was estimated considering matrices genotypic values, a mean heterosis of $15 \%$, and a mean of restricted sense 
heritability of 0.40 (LEROY et al., 1997; FERRÃO et al. 2008, MONTAGON, 2008).

\section{RESULTS AND DISCUSSION}

The analysis of variance indicated that the sources of variation: clones, years, and their interaction (clones $\times$ years) were significant by the $\mathrm{F}$ test at $5 \%$ probability for all characteristics evaluated. The significant effect of the interaction clones $\times$ years indicated inconsistent performance of clones over time. This interaction makes it difficult to improve perennial species because it results in a decrease in selection gains resulting from changes in genotype classification from year to year (RESENDE \& DUARTE, 2007).
The estimates of the coefficient of variation were comparable to the values observed in other studies and indicated good experimental precision (RODRIGUES et al., 2016, SOUZA et al., 2017; FERRÃO et al., 2008) (Table 1). This estimator, which associates the mean of the experiment with the residual variance, showed that the most difficult measure was the production of processed coffee followed by the number of plagiotropic branches. FERRÃO et al. (2008) and NASCIMENTO et al. (2010) reported a coefficient of variation between 20 and $30 \%$ for the production of processed coffee.

Genotypic variances of all traits evaluated were higher than the genotype $x$

Table 1 - Estimation of genetic parameters for plant height characteristics (PHEI), number of plagiotropic branches (NPLAG), number of rosettes (NROS), plagiotropic branch length (PLAGL), distance between rosettes (DROS), number of grains per rosette (GROS), leaf length (LLEN), leaf width (LWID), production of processed coffee (PROD), and number of days for maturation (NDAYS) evaluated in 130 clones over two years.

\begin{tabular}{|c|c|c|c|c|c|}
\hline Genetic Parameters & PHEI & NPLAG & NROS & PLAGL & DROS \\
\hline$\sigma_{g}^{2}$ & 0.03 & 676.93 & 1.21 & 0.07 & 0.21 \\
\hline$\sigma_{\text {gxa }}^{2}$ & 0.01 & 154.88 & 2.06 & 0.02 & 0.22 \\
\hline$\sigma_{\mathrm{e}}^{2}$ & 0.01 & 479.40 & 3.89 & 0.05 & 0.13 \\
\hline$r$ & 81.88 & 83.13 & 44.39 & 79.83 & 63.24 \\
\hline$\hat{\rho}$ & 57.42 & 51.63 & 16.89 & 48.41 & 38.36 \\
\hline $\mathrm{CV}_{\mathrm{e}}$ & 6.65 & 26.91 & 19.09 & 9.43 & 7.25 \\
\hline $\mathrm{CV}_{\mathrm{g}}$ & 10.53 & 31.99 & 10.64 & 10.92 & 9.43 \\
\hline $\mathrm{CV}_{\mathrm{g}} / \mathrm{CV}_{\mathrm{e}}$ & 1.58 & 1.18 & 1.21 & 1.16 & 1.30 \\
\hline Genetic Parameters & GROS & LLEN & LWID & PROD & NDAYS \\
\hline$\sigma_{\mathrm{g}}^{2}$ & 2.94 & 3.17 & 1.03 & 270.96 & 205.30 \\
\hline$\sigma_{\text {gxa }}^{2}$ & 10.14 & 0.23 & 0.09 & 67.39 & 46.93 \\
\hline$\sigma_{\mathrm{e}}^{2}$ & 5.70 & 0.43 & 0.11 & 160.47 & 96.34 \\
\hline $\mathbf{r}$ & 33.69 & 94.94 & 94.27 & 95.29 & 85.25 \\
\hline$\hat{\rho}$ & 15.65 & 82.75 & 82.83 & 62.80 & 58.89 \\
\hline $\mathrm{CV}_{\mathrm{e}}$ & 14.03 & 5.14 & 6.38 & 29.42 & 14.03 \\
\hline $\mathrm{CV}_{\mathrm{g}}$ & 10.08 & 13.96 & 19.17 & 38.23 & 4.75 \\
\hline $\mathrm{CV}_{\mathrm{g}} / \mathrm{CV}_{\mathrm{e}}$ & 0.71 & 2.71 & 3.00 & 1.29 & 1.46 \\
\hline
\end{tabular}

$\sigma_{\mathrm{g}}^{2}$ : genotype variance, $\sigma_{\mathrm{e}}^{2}$ : environmental variance, $\sigma_{\mathrm{p}}^{2}$ : phenotypic variance, $\mathrm{r}$ : individual repeatability, $\hat{\rho}$ : intraclass correlation, $\mathrm{CV}_{\mathrm{g}}$ : coefficient of genotype variation, $\mathrm{CV}_{\mathrm{e}}$ : coefficient of environmental variation, $\mathrm{CV}_{\mathrm{g}} / \mathrm{CV}_{\mathrm{e}}$ : ratio between the coefficients of genotypic and environmental of variation. 
years variance and environmental variance, except for the NROS and GROS characteristics (Table 1). The greater magnitude of the genotypic variance in relation to the environmental variance indicated a predominance of the genotype effect (clones) resulting from the differentiated genetic expression between genotypes. This condition is fundamental for obtaining genetic progress through the practice of selection.

Repeatability estimates were interpreted to quantify the differential performance of the plants over time. According to Resende, 2015, repeatability may be classified as low when values are less than 0.30 , average between 0.30 and 0.60 , and high when the estimates are higher than 0.60 . NROS, DROS and GROS characteristics presented estimates of repeatability that could be considered average, whereas, PHEI, NPLAG, PLAGL DROS, PROD, NDIAS, LLEN, and LWID presented estimates considered high, indicating that the number of evaluations used in this study supports the acquisition of gains from plant selection.

Estimates of the coefficient of genetic variation $\left(\mathrm{CV}_{\mathrm{g}}\right)$ above the coefficient of environmental variation $\left(\mathrm{CV}_{\mathrm{e}}\right)$ also characterize favorable conditions to obtain gains from selection. The estimates of the $\mathrm{CV}_{\mathrm{g}} / \mathrm{CV}_{\mathrm{e}}$ ratio showed an amplitude of 0.71 for GROS at 0.03 for LLEN indicating that the second characteristic was subject to greater environmental influence than was the first one. FERRÃO et al. (2008) reported values for this relationship close to unity for the production of processed coffee, similar to that observed in this study (Table 1).

Although, commercially the two botanical groups are known only as "Robusta coffee," separation of botanical varieties allows the systematic production of hybrid progenies, exploiting the hybrid vigor manifested in the intervarietal crossing, with the possibility of bringing together in the same genotype the best characteristics of the botanical varieties Conilon and Robusta. Natural hybrids that have the smallest size, resistance to drought of the Conilon, largest sieve, and resistance to pests and diseases of Robusta have stood out in field evaluations (RAMALHO et al., 2016; DALCOMO et al., 2015; DUBBERSTEIN et al., 2017). MONTAGNON et al. (2008) observed that on average the hybrid individuals presented a $15 \%$ higher productivity in comparison with their parents.

Different methods of multivariate statistics can be used to quantify genetic divergence. The principal component analysis allows for quantification of divergence between the genotypes in a plane of dispersion (CRUZ et al., 2014). The greater the proximity of two points in the graph, the greater the similarity between them in relation to the studied variables (ROCHA et al., 2005).

The first two principal components allowed the separation of the botanical varieties Robusta and Conilon, as well as their intervarietal hybrids, and represented the variability contained in the original data at $76 \%$ in the first year and $69 \%$ in the second year. It was observed that the hybrid individuals presented greater similarity with the botanical variety Conilon (Figure 1). We also observed some genotypes of the variety Robusta that were grouped far from the centroid point of their group, indicating non-characteristic polymorphisms of the botanical variety, or a mixture between the varieties, which should not be selected as hybridization matrices.

Although, the genotype $\times$ years interaction was significant, there was little difference in the grouping from one year to the next, which was associated with the higher repeatability estimates observed in this study. According to Cruz et al. (2014), the interaction of the simple type is characterized by minor alterations in the classification of genotypes performance. Considering the criteria of higher production of processed coffee and greater genetic diversity, 10 genotypes belonging to the variety Conilon and 10 belonging to the variety Robusta were selected for use in matrices in the development of hybrid progenies (Table 2).

Although, phenotypic values are measured, it is the additive genetic value that is responsible for transmitting characteristics from one generation to the next (RESENDE, 2015). Selection gain was estimated considering estimates of heritability in the strict sense and heterosis estimated as in FERRÃO et al. (2008) and MONTAGNON et al. (2008). Impossibility of estimating the additive values is because of the evaluation of unrelated clones. In this case the magnitude of the estimates is less important than the comparison between the most promising hybridizations (Table 2). It was observed that the matrices $16-1-81^{\mathrm{I}}, 9-1-82^{\mathrm{L}}$, and $13-1-61^{\mathrm{I}}$ of the botanical variety Robusta and the matrices $167^{\mathrm{I}}, 890^{\mathrm{E}}$, and $130^{\mathrm{I}}$ of the botanical variety Conilon presented greater potential to obtain gains with selection. 

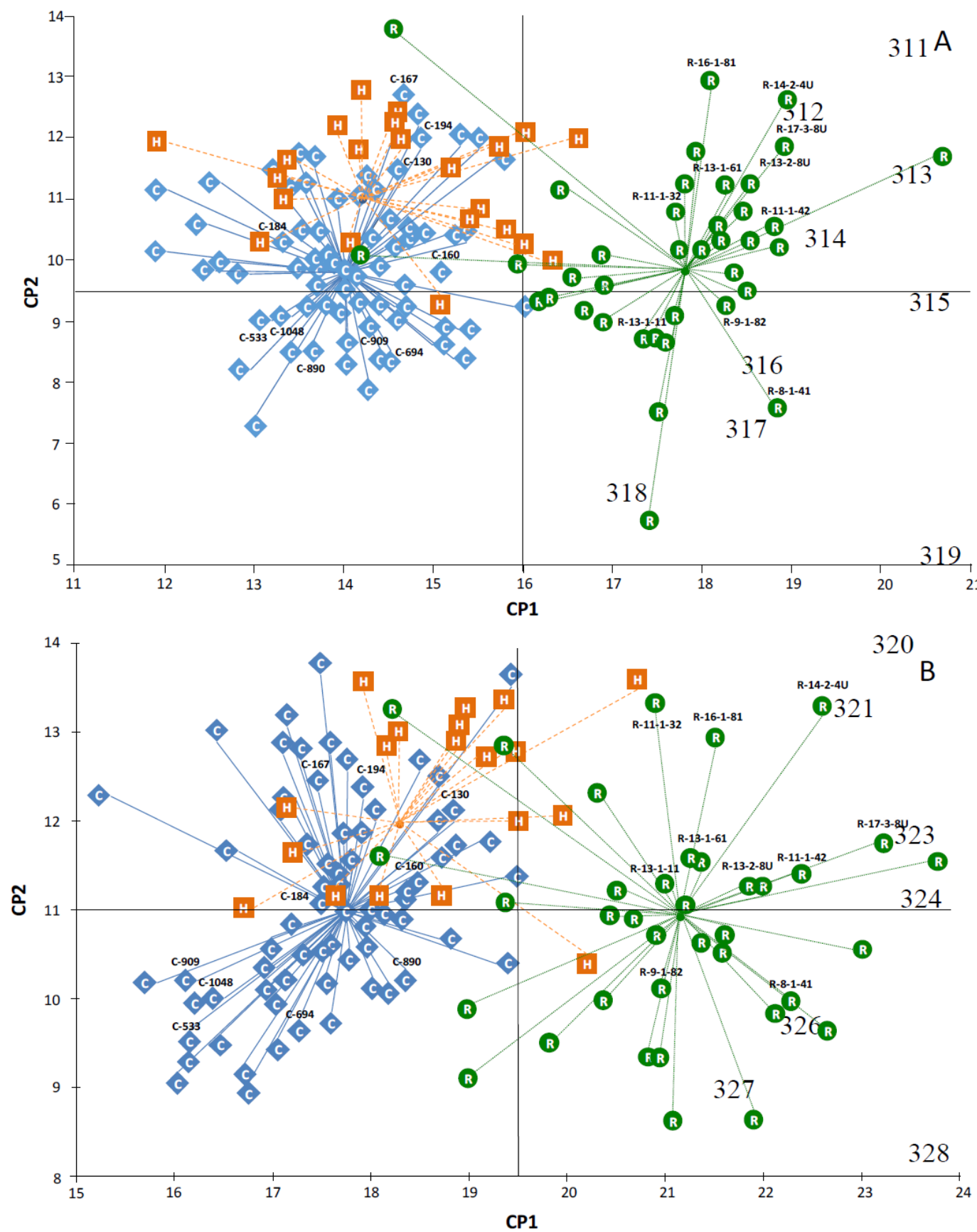

Figure 1 - Graphic dispersion of the first two principal components of 130 clones of the botanical varieties Conilon and Robusta and their intervarietal hybrids identified by the letters C, R, and H, respectively. The letters A and B identify the assessments carried out in the agricultural years 2014-2015 and 2015-2016, respectively. The genotypes selected to be used as matrices are identified in the figure. 
Table 2 - Estimated selection gain with recombination of selected matrices in partial diallel scheme of $10 \times 10$ parents with three crosses per parent.

\begin{tabular}{|c|c|c|c|c|c|c|c|}
\hline $\begin{array}{l}\text { Robusta } \\
\text { Parent }\end{array}$ & $\begin{array}{c}\text { Conilon } \\
\text { Parent }\end{array}$ & $\begin{array}{c}\text { Distance } \\
2014-2015\end{array}$ & $\begin{array}{c}\text { Distance } \\
2015-2016\end{array}$ & $\begin{array}{c}\text { SG } \\
2014-2015\end{array}$ & $\begin{array}{c}\text { SG\% } \\
2014-2015\end{array}$ & $\begin{array}{c}\mathrm{SG} \\
2015-2016\end{array}$ & $\begin{array}{c}\text { SG\% } \\
2015-2016\end{array}$ \\
\hline & $694^{\mathrm{E}}$ & 8.3 & 10.7 & 7.9 & 23.5 & 18.7 & 35.6 \\
\hline \multirow[t]{3}{*}{$8-1-41^{\mathrm{E}}$} & $890^{\mathrm{E}}$ & 9.9 & 8.4 & 9.3 & 27.6 & 21.8 & 41.5 \\
\hline & $909^{\mathrm{E}}$ & 8.9 & 13.9 & 9.8 & 28.9 & 15.4 & 29.3 \\
\hline & $890^{\mathrm{E}}$ & 10.1 & 8.9 & 11.7 & 34.6 & 23.9 & 45.4 \\
\hline \multirow[t]{3}{*}{$11-1-42^{I}$} & $909^{\mathrm{E}}$ & 8.9 & 14.4 & 12.1 & 35.9 & 17.5 & 33.2 \\
\hline & $130^{I}$ & 7.4 & 7.4 & 12.7 & 37.5 & 21.9 & 41.5 \\
\hline & $909^{\mathrm{E}}$ & 6.9 & 11.9 & 11.0 & 32.7 & 12.8 & 24.3 \\
\hline \multirow[t]{3}{*}{$11-1-32^{I}$} & $130^{\mathrm{I}}$ & 6.0 & 5.1 & 11.6 & 34.2 & 17.2 & 32.6 \\
\hline & $160^{\mathrm{I}}$ & 5.1 & 6.5 & 9.2 & 27.2 & 15.2 & 28.9 \\
\hline & $130^{\mathrm{I}}$ & 6.9 & 5.5 & 10.4 & 30.8 & 24.7 & 47.0 \\
\hline \multirow[t]{3}{*}{$13-1-61^{I}$} & $160^{I}$ & 6.4 & 6.1 & 8.0 & 23.7 & 22.8 & 43.3 \\
\hline & $167^{\mathrm{I}}$ & 7.1 & 8.1 & 9.4 & 27.8 & 28.2 & 53.7 \\
\hline & $160^{I}$ & 6.9 & 7.2 & 8.5 & 25.2 & 18.4 & 35.0 \\
\hline \multirow[t]{3}{*}{$13-2-8 U^{I}$} & $167^{\mathrm{I}}$ & 7.7 & 9.6 & 9.9 & 29.2 & 23.8 & 45.3 \\
\hline & $184^{\mathrm{I}}$ & 10.5 & 9.3 & 8.4 & 24.9 & 15.5 & 29.5 \\
\hline & $167^{\mathrm{I}}$ & 6.5 & 8.7 & 15.4 & 45.5 & 31.1 & 59.1 \\
\hline \multirow[t]{3}{*}{$16-1-81^{I}$} & $184^{\mathrm{I}}$ & 10.2 & 9.3 & 13.9 & 41.2 & 22.8 & 43.3 \\
\hline & $194^{\mathrm{I}}$ & 6.3 & 7.7 & 13.5 & 39.8 & 28.3 & 53.8 \\
\hline & $184^{\mathrm{I}}$ & 11.6 & 11.6 & 7.1 & 21.1 & 18.6 & 35.3 \\
\hline \multirow[t]{3}{*}{$14-2-4 U^{\mathrm{L}}$} & $194^{\mathrm{I}}$ & 7.8 & 10.0 & 6.7 & 19.7 & 24.1 & 45.8 \\
\hline & $1048^{I}$ & 11.9 & 14.7 & 6.5 & 19.3 & 25.7 & 48.9 \\
\hline & $194^{\mathrm{I}}$ & 6.9 & 6.7 & 7.2 & 21.4 & 18.7 & 35.5 \\
\hline \multirow[t]{3}{*}{$13-1-11^{\mathrm{L}}$} & $1048^{I}$ & 7.2 & 10.1 & 7.1 & 21.0 & 20.3 & 38.6 \\
\hline & $533^{\mathrm{T}}$ & 8.2 & 10.9 & 10.3 & 30.6 & 14.3 & 27.2 \\
\hline & $1048^{\mathrm{I}}$ & 11.4 & 14.9 & 8.4 & 24.9 & 24.5 & 46.6 \\
\hline \multirow[t]{3}{*}{$17-3-8 U^{L}$} & $533^{\mathrm{L}}$ & 11.8 & 15.7 & 11.7 & 34.5 & 18.5 & 35.2 \\
\hline & $694^{\mathrm{E}}$ & 9.6 & 13.3 & 9.1 & 27.0 & 21.1 & 40.0 \\
\hline & $533^{\mathrm{L}}$ & 9.9 & 10.4 & 13.6 & 40.3 & 23.9 & 45.4 \\
\hline \multirow[t]{2}{*}{$9-1-82^{L}$} & $694^{\mathrm{E}}$ & 7.4 & 7.9 & 11.1 & 32.9 & 26.4 & 50.3 \\
\hline & $890^{\mathrm{E}}$ & 8.9 & 5.5 & 12.5 & 37.0 & 29.6 & 56.2 \\
\hline
\end{tabular}

E: early cycle, I: intermediate cycle, L: late cycle, Distance: distance measured in the first two axes of the principal components in the first and second evaluation, SG: selection gain in sacs benefited per hectare. SG\%: percentage selection gain.

\section{CONCLUSION}

The selected genotypes presented greater genetic divergence associated with better agronomic performance, with a tendency of grouping between the botanical varieties Conilon and Robusta. The principal component analysis using reference points was adequate to characterize the genetic diversity between the botanical varieties Conilon and Robusta. The predicted gains were interpreted to identify the matrices with the highest potential for hybridization that meet the best characteristics of the botanical varieties Conilon and Robusta associated with the expression of the hybrid vigor.

\section{ACKNOWLEDGEMENTS}

The authors thank to the Conselho Nacional de Desenvolvimento Científico e Tecnológico (CNPq) for the scholar ship grant. We also gratefully acknowledge the Brazilian Consortium for Consórcio Brasileiro de Pesquisa e Desenvolvimento do Café (CPC) for financial support. 


\section{DECLARATION OF CONFLICTING INTERESTS}

The authors declared no potential conflicts of interest with respect to the research, authorship, and/or publication of this article.

\section{REFERENCES}

BATISTA-SANTOS, P. et al. The impact of cold on photosynthesis in genotypes of Coffea spp.- photosystem sensitivity, photoprotective mechanisms and gene expression. Journal of plant physiology, v.168, n.8, p.792-806. 2011. Available from: $<$ http://dx.doi.org/10.1016/j.jplph.2010.11.013>. Accessed: Mar. 18, 2018. doi: 10.1016/j.jplph.2010.11.013.

CRUZ, C. D. et al. Modelos biométricos aplicados ao melhoramento genético. 3. ed. Viçosa: Universidade Federal de Viçosa, 2014. 668 p

DALCOMO, J. et al. Evaluation of genetic divergence among clones of conilon coffee after scheduled cycle pruning. Genetics and Molecular Research, v.14, p.15417-15426. 2015. Available from: <http://dx.doi. org/10.4238/2015>. Accessed: Mar. 18, 2018. doi: 10.4238/2015.

DAVIS, A. et al. An annotated taxonomic conspectus of the genus Coffea (Rubiaceae). Botanical Journal of the Linnean Society,v.152, n. 4, p. 465 512, 2006. Available from: $<$ http://dx.doi.org/10.1111/j.1095-8339.2006.00584. x>. Accessed: Mar. 18, 2018. doi: 10.1111/j.1095-8339.2006.00584.x.

DIAS, L. A. S. et al. A priori choice of hybrid parents in plants. Genetics and Molecular Research, v. 3, n.3, p. 356-368, 2004. Available from: <http://www.funpecrp.com.br>. Mar. 18, 2018.

DUBBERSTEIN, D. et al. Dry matter in fruits, leaves and plagiotropic branches of grow coffee trees in the Western Amazon. Coffee Science, v.12, p.74-81, 2017. Available from: <http://dx.doi.org/10.25186/ cs.v12i1.1241>. Accessed: Mar. 18, 2018. doi: 10.25186/cs.v12i1.1241.

FERRÃO, R. G. et al. Genetic parameters in Conilon coffee. Pesquisa Agropecuária Brasileira, v.43, n.1, p.61-69. 2008. Available from: <http:/ dx.doi.org/10.1590/S0100-204X2008000100009>. Accessed: Mar. 18, 2018. doi: 10.1590/S0100-204X2008000100009.

INTERNATIONAL COFFEE ORGANIZATION. Annual review 2015/16: IOC document. London, 2016. 40 p. Available from: <http:// www.ico.org>. Accessed: Dec. 18, 2017.

LEROY, T. et al. Reciprocal recurrent selection applied to Coffea canephora Pierre. III. Genetic gains and results of first cycle intergroup crosses. Euphytica, v. 95, n. 3, p. 347-354, 1997. Available from: < http://dx.doi.org/10.1007/BF00033776>. Accessed: Mar. 18, 2018. doi: 10.1007/BF00033776.

MARCOLAN, A. L. et al. Cultivo dos cafeeiros conilon e robusta para Rondônia. Porto Velho: Embrapa Rondônia, 2009. 67p. Available from: $<$ http://www.sapc.embrapa.br/arquivos/consorcio/publicacoes tecnicas/sp33-cafe.pdf $>$ Accessed: December 18, 2017.

MONTAGNON, C. et al. Amélioration génétique du caféier Coffea canephora Pierre: connaissances acquises, stratégies et perspectives. Cahiers Agricultures,v.21, n.2-3, p.143-153, 2012. Available from: \http://dx.doi.org/10.1684/agr.2012.0556>. Accessed: Mar. 18, 2018. doi: 10.1684/agr.2012.0556.

MONTAGNON, C. et al. Heterozygous genotypes are efficient testers for assessing between-population combining ability in the reciprocal recurrent selection of Coffea canephora. Euphytica, v. 160, n. 1, p. 101110, 2008. Available from: <http://dx.doi.org//10.1007/s10681-0079561-9>. Accessed: Mar. 18, 2018. doi: 10.1007/s10681-007-9561-9.
NASCIMENTO, M. et al. Alteration of the centroid method to evaluate genotypic adaptability. Pesquisa Agropecuária Brasileira,v.44, p.263-269, 2009. Available from: <http://dx.doi.org/10.1590/S0100204X2009000300007>. Accessed: Mar. 18, 2018. doi: 10.1590/S0100$204 X 2009000300007$.

NASCIMENTO, M. et al. Adaptability and stability based on nonparametric regression in coffee genotypes. Pesquisa Agropecuária Brasileira,v.45, n.1, p.41-48, 2010. Available from: <http://dx.doi. org/10.1590/S0100-204X2010000100006>. Accessed: Mar. 18, 2018. doi: 10.1590/S0100-204X2010000100006.

PARTELLI, F., et al. Characterization of the main lipid components of chloroplast membranes and cold induced changes in Coffea spp. Environmental and Experimental Botany, v.74, p.194-204. 2011 Available from: $<$ https://doi.org/10.1016/j.envexpbot.2011.06.001>. Accessed: Mar. 18, 2018. doi: 10.1016/j.envexpbot.2011.06.001.

RAMALHO, A. R. et al. Genetic gain in the productivity of processed coffee from the selection of clones of 'Conilon' coffee. Revista Ciência Agronômica, v.47, n.3, p.516. 2016. Available from: <http:// dx.doi.org/10.5935/1806-6690.20160062>. Accessed: Mar. 18, 2018. doi: $10.5935 / 1806-6690.20160062$.

RESENDE, M. D. V. Genética Quantitativa e de Populações. 1. ed. Visconde do Rio Branco: Suprema, 2015. v. 1. 422p.

RESENDE, M. D. V. et al. Precision and quality control in variety trial. Pesquisa Agropecuária Tropical, v.37, n.3, p.182-194. 2007. Available from: <https://www.revistas.ufg.br/pat/article/view/1867>. Accessed: Mar. 18, 2018.

ROCHA, R. B. et al. Evaluation of the centroid method for study environment adaptability of clones of Eucalyptus grandis. Ciência Florestal, v.15, p.255-266, 2005. Available from: <http://dx.doi. org/10.5902/198050981863>. Accessed: Mar. 18, 2018. doi: $10.5902 / 198050981863$.

ROCHA, R. B. et al. Melhoramento de Coffea canephora - Considerações e Metodologias. In: MARCOLAN, A. L. \& ESPINDULA, M. (Eds.). Café na Amazônia. Brasília, DF: Embrapa, v. 1, 2015. p.217-236. Available from: $<$ http://www.sapc.embrapa.br/arquivos/consorcio/publicacoes_tecnicas/Livro_Cafe_na_Amazonia_2015.pdf $>$ Accessed: Dec. 18, 2017.

RODRIGUES W. P. et al. Assessment of genetic divergence among coffee genotypes by Ward-MLM procedure in association with mixed models. Genetics and Molecular Research, v.15.n.2, p.1-7, 2016. Available from: $<$ http://dx.doi.org/10.4238/gmr.15027889>. Accessed: Mar. 18, 2018. doi: 10.4238/gmr.15027889.

SANTOS, A. V. et al. Reaction of Coffea canephora clones to the root knot nematode, Meloidogyne incognita. African Journal of Agricultural Research, v.12, n.11, p.916-922. 2017. Available from: $<$ http://dx.doi.org/10.5897/AJAR2016.11999>. Accessed: Mar. 18, 2018. doi: 10.5897/AJAR2016.11999.

SOUZA, C. A. et al. Genetic components for fruit development and ripening of Coffea canephora Pierre ex A. Froehner. Coffee Science, v.12, n.3, p.355-364. 2017. Available from: $<$ http://dx.doi.org/10.25186/ cs.v12i3.1295>. Accessed: Mar. 18, 2018. doi: 10.25186/cs.v12i3.1295.

SOUZA, F. F. et al. Molecular diversity in Coffea canephora germplasm conserved and cultivated in Brazil. Crop breeding and applied biotechnology, v.13, n.4, p. 221-227. 2013. Available from: $<$ http://dx.doi.org/10.1590/S1984-70332013000400001>. Accessed: Mar. 18, 2018. doi: 10.1590/S1984-70332013000400001. 